\title{
Cortisol and lactate levels in Atlantic salmon Salmo salar developing infectious anaemia (ISA)
}

\author{
Yngvar A. Olsen ${ }^{1}$, Knut Falk ${ }^{2}$, Ola B. Reite ${ }^{1}$ \\ ${ }^{1}$ Institute of Aquaculture and Fish Diseases, Norwegian College of Veterinary Medicine, Box 8146 Dep., \\ N-0033 Oslo 1, Norway \\ ${ }^{2}$ Department of Virology, National Veterinary Institute, Box 8156 Dep., N-0033 Oslo 1, Norway
}

\begin{abstract}
Atlantic salmon Salmo salar presmolts were intraperitoneally injected with an organ homogenate from individuals of the same species suffering from an acute outbreak of infectious salmon anaemia (ISA). Mortality started in the infected group $18 \mathrm{~d}$ after injection. Blood samples from the diseased group showed that these fish had elevated plasma cortisol levels compared with control fish. The cortisol level was correlated to the severity of the anaemia condition, as represented by haematocrit values. Plasma lactate levels were also elevated in diseased fish, but there was a greater variability in the level of this parameter.
\end{abstract}

\section{INTRODUCTION}

In salmonids cortisol is the principal corticosteroid. High cortisol levels are normally associated with stressful conditions like handling, toxicants in the water, and in situations where the fish can perceive threat. Increased levels of cortisol in plasma of fish have also been measured during various disease conditions (Donaldson 1981). However, a rise in plasma cortisol does not seem to be an invariable consequence of disease (Laidley et al. 1988).

In mammals a consequence of infection is a rise in glucocorticosteroid hormones in plasma. However, the response is not very strong and is rather short-lived (Beisel 1977). An injection of antigen into rats leads to an increase in plasma levels of glucocorticosteroids (Besedovsky et al. 1975). Endotoxin injected into fish or mammals produces a rise in plasma corticosteroids (Melby et al. 1960, Wedemeyer 1969). Glucocorticosteroids are known to affect the immune system of mammals, usually in a suppressive way (Munck et al. 1984). In fish, effects of corticosteroids on immune function and disease susceptibility have been described by many authors, even with physiological concentrations of hormone (reviewed by Barton \& Iwama 1991).
Infectious salmon anaemia (ISA) is a recently described disease condition in Atlantic salmon Salmo salar (L.) in Norway. The infectious nature of the disease, blood disturbances, and pathology are described in papers by Thorud \& Djupvik (1988), Evensen et al. (1991), Thorud (1991, in press), and Thorud et al. (in press). The disease is suspected to be caused by a virus. A characteristic change following the disease is the extreme anaemia due to haemolysis of red blood cells. Another prominent change is the degeneration of liver tissue. Thorud (in press) observed that during development of ISA there were changes in the numbers of white blood cells similar to those seen in salmonids following an acute handling stress (Pickering et al. 1982). However, a stress response can be introduced by a lack of blood cells per se without an accompanying disease condition. Artificially induced anaemia by gradual removal of blood elicits a catecholamine response in rainbow trout (Iwama et al. 1987, Perry et al. 1989).

The purpose of the present study was to investigate the cortisol response in Atlantic salmon during development of infectious anaemia. Furthermore, we wanted to test the hypothesis that the anaemia in ISAinfected fish leads to anaerobic metabolism in these individuals. This could be reflected in their blood lactate levels. 


\section{MATERIALS AND METHODS}

The experiment was conducted at the Vikan AkvaVet Research Station, 7810 Alhusstrand, Norway, in March and April 1991. Two tanks of approximately 1301 water volume each were used for the study. The tanks were covered with separate lids. Two hundred Atlantic salmon presmolts of average size $40 \mathrm{~g}$, reared in fresh water, were taken from the nearby farm Lokkarfisk A/S. One hundred fish were randomly assigned to each tank. Water quality parameters were logged every hour during the experimental period. The water temperature varied between 9.9 and $10.2^{\circ} \mathrm{C}$. Seawater was added to the supply fresh water to give a final salinity varying between 14 and 16 ppt. $\mathrm{pH}$ was maintained at 7.6 to 7.7 The oxygen content of the supply water varied between 10.1 and $11.1 \mathrm{mg} \mathrm{l}^{-1}$. The water flow to each tank was set at $0.8 \mathrm{l}(\mathrm{kg}$ biomassi ${ }^{-1}$ minin $^{-1}$. The fish were fed by hand twice per day at $1 \%$ of their biomass $\mathrm{d}^{-1}$. They were given Skretting Tess Elite commercial dry feed. Five days after injection, the fish in Tank 1 showed reduced feed intake and were then fed ad libitum.

The individuals in Tank 1 were intraperitoneally injected with mixed internal organ homogenate from ISA diseased Atlantic salmon (size 3 to $400 \mathrm{~g}$ ) from an acute outbreak at a marine fish farm. Only IPN negative liver, spleen, and kidney were used. One part tissue was mixed with 9 parts Earle's balanced salt solution (EBSS). The mixture was homogenized, centrifuged at 13000 $\times g$ for $45 \mathrm{~min}$ and passed through a filter sequence of diminishing pore size $(3.0,1.2,0.45$, and $0.22 \mu \mathrm{m}$; Millipore, Bedford, MA, USA). The filtrate was kept at $-70^{\circ} \mathrm{C}$ until use. Before injection, the filtrate was diluted $1: 5$ in EBSS. The injection dose was $0.01 \mathrm{ml}$ (g body wt $)^{-1}$. The fish in Tank 2 were not injected but were kept as controls. The injection per se has no effect on the long term cortisol level (unpubl. obs.).

Blood sampling started $20 \mathrm{~d}$ after injection; $2 \mathrm{~d}$ after the first day of mortality in Tank 1 . Feed was not given and the fish were not disturbed the day prior to sampling. A batch of fish (on average 7 individuals) were caught with the dip-net and immediately put under anaesthesia. Then the fish-tank lid was put on and the fish were not disturbed until the next batch-taking. Next sampling in the same tank was not done until at least $6 \mathrm{~h}$ later; normally $8 \mathrm{~h}$. In brown trout this time interval is sufficient for cortisol to return almost to basal levels after an acute stress (Pickering et al. 1982). Two batches of fish were sampled each day in Tank 1 ; only one in Tank 2. Tank 2 was sampled after the sampling of the first batch in Tank 1 was finished. Possible diel variations in cortisol levels were ignored as these have been shown to be small in salmonids (Pickering \& Pottinger 1983, Thorpe et al. 1987). Sampling was ter- minated after $3 \mathrm{~d}$. The anaesthesia bath consisted of a $200 \mathrm{mg} \mathrm{I}^{-1}$ solution of tricaine methanesulphonate (MS-222, Sigma Chemical Co., St. Louis, MO, USA) as a rapid immobilizer When immobilized, the fish were transferred to a $80 \mathrm{mg} \mathrm{l}^{-1} \mathrm{MS}-222$ solution. The fish stayed in anaesthesia for up to $20 \mathrm{~min}$, depending on the number of fish in that batch. Blood samples were taken from the caudal vessels using heparinized Venoject vacuum tubes (Terumo Europe N.V., Leuven, Belgium). The tubes were immediately put on ice and not treated further until all samples in that batch were taken.

Subsamples of the same blood sample were used both for lactate and cortisol analysis. Samples for lactate analysis were taken from whole blood after deproteinization with perchloric acid, according to the procedure described in Boehringer Mannheim kit no. 139084. Not all fish sampled for cortisol were tested for lactate. A total of 54 iandom samples (11 firom control fish and 43 from injected fish) were analysed. Haematocrit was measured using a Bayer Compur minicentrifuge $M$ 1100. Plasma was separated from cells by centrifugation and kept frozen at $-70^{\circ} \mathrm{C}$ until cortisol analysis.

The basic cortisol analysis procedure is described in Abraham et al. (1977). Analysis was performed directly on Atlantic salmon plasma without extraction. Standards were prepared by dissolving hydrocortisone (Sigma) in ethanol and serially diluting this solution with $0.1 \mathrm{M}$ phosphate buffer, $\mathrm{pH} 7.5$, containing $1 \%$ bovine serum albumin (BSA). Plasma was diluted 6-fold with the same phosphate buffer as used for standards. In high level cortisol samples, this dilution factor was increased. A solution of trichloroacetic acid $\left(7.5 \mathrm{~g} \mathrm{l}^{-1}\right)$ and sodium hydroxide $\left(2.25 \mathrm{~g} \mathrm{l}^{-1}\right)$ was added to prevent protein binding. The tracer was $\left(1,2,6,7-{ }^{3} \mathrm{H}\right)$ cortisol (Amersham International plc, Amersham, UK) diluted with ethanol to an activity of $10 \mu \mathrm{Ci} \mathrm{ml}{ }^{-1}$ ). The antibody source was anticortisol rabbit serum (No. F3-314, Endocrine Sciences, Tarzana, CA, USA). It was added to give about $33 \%$ binding of total radioactivity. Samples were counted in Insta-Gel scintillation fluid (Packard, Groningen, Netherlands) on a Packard Tricarb 1900 CA liquid scintillation counter. The crossreactivity of the antiserum is given by the producer. The sensitivity of the standard curve was $0.55 \mathrm{nM}$. The intra-assay coefficient of variation was $4.0 \%$ and the inter-assay CV was $14.6 \%$. Cortisol-free blanks gave a count of 2 to $3 \%$ of total count.

Statistical analysis of the results was performed using PC-SAS software (SAS Institute Inc., Cary, NC, USA). The product-moment correlation coefficient was calculated and tested for significance against the no correlation zero hypothesis through the procedure Correlation. The significance level was chosen at 0.05 . 


\section{RESULTS}

Gross pathological signs of diseased fish corresponded with previously published findings in fish suffering from ISA (Thorud \& Djupvik 1988, Evensen et al. 1991). No mortality occured in Tank 2.

Haematocrit values from the injected fish showed that the individuals were in different stages of disease development. It has previously been shown that haematocrit is an indicator of stage of disease development in ISA (Thorud in press). Haematocrits from 16 sampled control fish ranged from 32 to 53, while haematocrits from 55 injected fish ranged from 12 to 58. Analysis of plasma cortisol showed that there was a large variability of levels between individuals. The control fish showed a range of cortisol levels from 22 to $306 \mathrm{nM}$, while the sampled injected fish ranged from 39 to $635 \mathrm{nM}$. A scatter diagram indicated that there was a negative correlation between haematocrit and cortisol values in the injected fish (Fig. 1). A correlation analysis gave an r-value of -0.445 , which is sufficient to reject the no-correlation hypothesis ( $\mathrm{p}=0.0007)$. Control fish showed a positive correlation ( $r=0.342$ ) but the effect was not significant $(\mathrm{p}=0.195)$.

Analysis of blood lactate showed that there was a large individual variability. The levels varied from 0.3 to $2.5 \mathrm{mM}$ in control fish and from 0.9 to 15.1 in injected fish. A similar scatter diagram of lactate against haematocrit levels was prepared and is presented in Fig. 2. There was an increase in lactate levels correlated with a fall in haematocrit levels in injected fish. Correlation analysis gave an r-value of -0.312 , which indicates a significant effect of the anaemia condition on blood lactate levels $(p=0.042)$. There was a larger variability in lactate levels between individuals in the late stages of disease development. Control fish showed a significantly positive correlation with haematocrit $(r=0.792$, $p=0.004)$. This could be an effect related to the time in deep anaesthesia and we thus proceeded to test the correlation between time in anaesthesia and levels of cortisol, lactate, and haematocrit in control fish. Time in anaesthesia was not registered exactly but since the sequence of sampling was known, 1 min was assigned as approximate blood sampling time for each fish. It turned out that cortisol showed no significant correlation with time in anaesthesia ( $\mathrm{r}=0.154, \mathrm{p}=0.569$ ), however, lactate and haematocrit both showed a highly significant positive correlation $(\mathrm{r}=0.939, \mathrm{p}=0.0001 ; \mathrm{r}=0.916, \mathrm{p}=0.0001$, respectively).

\section{DISCUSSION}

The findings in the present experiment indicate that cortisol and lactate levels in blood plasma increase during the development of the disease condition described as infectious salmon anaemia.

The plasma levels of cortisol in Atlantic salmon are not very well investigated. Unstressed levels have

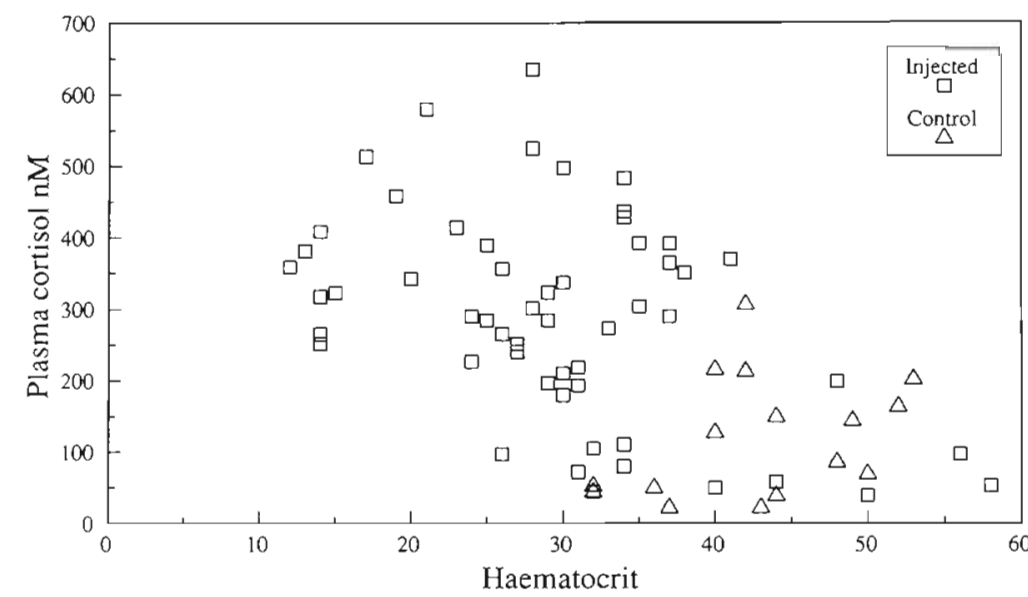

Fig. 1. Salmo salar. Individual plasma cortisol values and corresponding haematocrit values in Atlantic salmon during outbreak of infectious salmon anemia. Disease was artificially induced by injecting organ homogenate from naturally diseased fish. Control fish were not injected and stayed in a separate tank

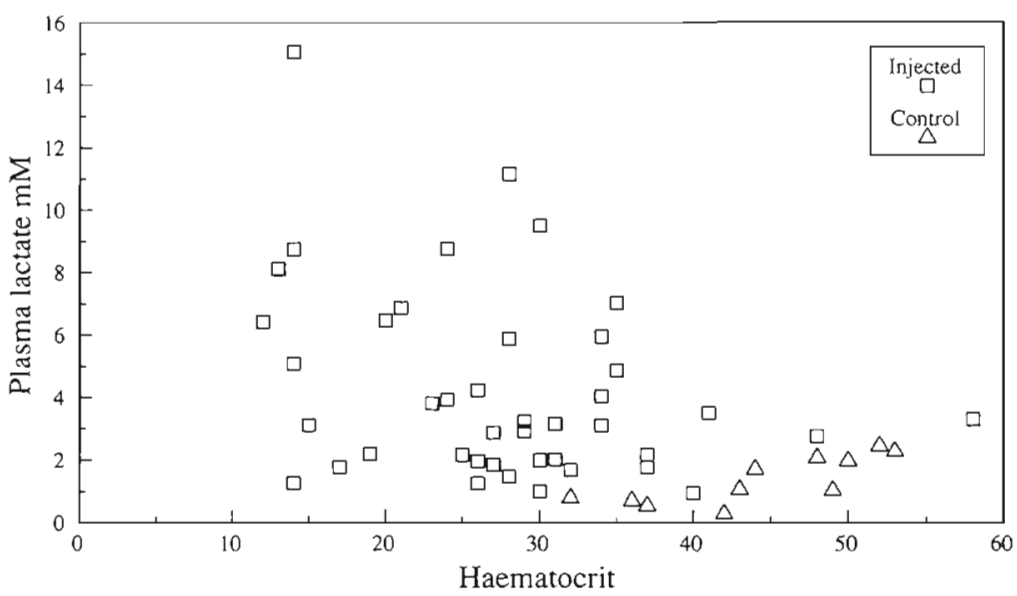

Fig. 2. Salmo salar. Individual plasma lactate values and corresponding haematocrit values in Atlantic salmon during outbreak of infectious salmon anemia. Individuals as in Fig. 1, but only 54 were sampled for lactate 
been overestimated in some cases, probably due to disturbance of the fish prior to sampling Thorpe et al. (1987) found a level of less than $10 \mathrm{ng} \mathrm{ml}^{-1}$ ( $28 \mathrm{nM}$ ) in the daytime throughout the year. These levels are in good agreement with results in brown trout Salmo trutta (Pickering \& Duston 1983, Pickering \& Pottinger 1983), and they are also in the same range as our own unpublished results in Atlantic salmon. Levels of plasma cortisol after acute stress are more variable, but may reach 70 to $250 \mathrm{ng} \mathrm{ml}^{-1}$ (193 to $690 \mathrm{nM}$ ) 0.5 to $1 \mathrm{~h}$ after stress (unpubl. results). Physiological processes such as smolting increase plasma cortisol levels (Langhorne \& Simpson 1981) up to between 20 and $25 \mathrm{ng} \mathrm{ml}^{-1}$ (55 to $69 \mathrm{nM}$ ) late in the smolting period (Stefansson et al. 1989).

In the present experiment, control cortisol levels were higher than expected. The most probable cause for this is disturbance of the control fish while sampling Tank 1 . Tank 2 was always sampled after Tank 1 , and the tanks were located next to each other. A second possibility is that the salinity of the water (15 ppt) could have led to osmotic stress. Thirdly, if the fish were in the late phase of the smoltification process they could have had increased levels of cortisol due to the endocrine changes associated with the parr-smolt transformation. The fish showed morphological signs of smolting, but levels of $\mathrm{Na}^{+}, \mathrm{K}^{+}$-ATPase in gills were not measured. Nevertheless, anaemic fish showed higher cortisol levels than controls. In the terminal stages of the disease (haematocrit $<20$ ), cortisol levels were in the same range as seen in acutely stressed fish. Considering the long-term development of the disease, these levels are high. Chronically stressed fish usually have cortisol levels much below acute levels, and complete adaptation to the stressor may occur (Pickering \& Stewart 1984, Tam et al. 1987).

The literature on cortisol elevation due to disease in fish is rather sparse. Fagerlund (1967) reported high plasma cortisol concentrations in diseased and moribund sockeye salmon Oncorhyncus nerka during sexual maturation. Similar observations were made by Donaldson \& Fagerlund (1968) and Fagerlund \& McBride (1969). Simpson (1975/76) observed high plasma cortisol levels in rainbow trout O. mykiss infected with Myxobacterium. Donaldson (1981) quoted unpublished observations by Donaldson \& Dye (1976) and Donaldson et al. (1980). These authors found that cortisol levels increase during bacterial kidney disease (Renibacterium salmoninarum) infection and Cryptobia-infection in pink 10 . gorbuscha) and coho (O. kisutch) salmon. Donaldson \& Dye (1976; in Donaldson 1981) also found that plasma cortisol levels increased with increasing severity of the bacterial kidney disease infection. However, Suzumoto et al. (1977) found that plasma levels of cortisol could have decreased with the progression of BKD development in coho salmon. Pickering \& Christie (1981) found marked elevations of circulating cortisol in brown trout Salmo trutta due to Saprolegnia infection, but not due to ectoparasites. In an experimental infection study by Laidley et al. (1988) no plasma cortisol elevation could be shown to result from Cryptobia salmositica infection in rainbow trout. Rand \& Cone (1990) could not detect any increase in plasma cortisol level due to disease in rainbow trout experimentally infected with Ichtyophonus hoferi. Thus, the literature data are equivocal on this issue. To our knowledge there are no results on cortisol levels in fish suffering from viral diseases.

One possible explanation of the observed high levels of cortisol in the present experiment is that the fish sense the progressive breakdown of organ systems during the disease development. A reduced oxygen availability in the tissues due to failure of transport from the gills could be one potential stress factor. Hypoxemia is known to elicit catecholamine secretion in the rainbow trout (Perry et al. 1989). Whether this condition also elicits cortisol secretion is not known.

Interleukin-1 (IL-1) is a product of activated monocytes and macrophages during disease, and this substance is able to elicit the secretion of ACTH from the rat pituitary, either by direct effect on corticotropic cells in the anterior pituitary (Woloski et al. 1985, Bernton et al. 1987) or by an effect on the hypothalamus to produce corticotropin releasing factor (Berkenbosch et al. 1987, Sapolsky et al. 1987). Preliminary evidence for the presence of an IL-1-like substance in fish is provided by Clem et al. (1985). However, to be able to explain the present results this demands a continuous, ongoing immune reaction through the final stages of disease development. Also, the increase in corticosteroid levels in rat plasma observed by Besedovsky et al. (1975) were only 2 to 3 times the basal level. It is therefore unlikely that this is the response observed in the present experiment.

A third possible explanation is a reduction in the metabolic clearance rate of corticosteroids. This is a commonly observed phenomenon in certain liver and kidney diseases in mammals (Ganong 1989). If this rate is diminished in diseased fish due to liver damage (characteristic of the ISA condition; cf. Evensen et al. 1991), then an increase in plasma concentration of cortisol would follow. This explanation would possibly also resolve some of the equivocal conclusions from the various studies on fish diseases, since different diseases show different levels of injury to the liver.

The anaesthetization protocol used in the present study is sufficient for preventing a rise in plasma cortisol concentration. However, a side effect of anaesthetization is suppression of the respiratory centre of the medulla (Iwama et al. 1989). This effect is accompa- 
nied by hypoxia, rise in blood $\mathrm{CO}_{2}$-tension and adrenaline levels, and fall in $\mathrm{pH}$. These conditions cause the red cells to swell (Soivio \& Nikinmaa 1981) and can be observed as an increase in haematocrit (Lowe-Jinde \& Niimi 1983). This was apparent in the present study by the positive correlation between haematocrit and time in anaesthesia in the control fish. This effect will also influence the estimation of disease development. The random sampling procedure used will lessen the error, since time in anaesthesia will not be related to stage of disease development. However, greater variability in results can be expected. Haemoglobin concentration would probably be a better parameter for estimation of disease condition since this parameter is not significantly influenced by time in anaesthesia (Lowe-Jinde \& Niimi 1983).

Blood lactate, being the end product of anaerobic metabolism in salmonids, is also influenced by time in anaesthesia (Houston et al. 1971, Soivio et al. 1977). This was apparent in our control fish which showed increased levels along with time in anaesthesia. This is probably a result of the reduced respiratory capacity, forcing the tissues to convert to anaerobic metabolism. Soivio et al. (1977) found that the lactate levels in rainbow trout before and after $15 \mathrm{~min}$ of neutralized tricaine methanesulphonate anaesthetization were 0.146 and $0.225 \mathrm{~g} \mathrm{l}^{-1}$ (1.6 and $2.5 \mathrm{mM}$ ). Since haematocrit also increases with time in anaesthesia, this explains the positive and significant correlation between haematocrit and lactate in our control fish. Generally, the control fish in the present experiment all had relatively low lactate levels compared to the average injected fish. The very high levels found in some diseased fish with haematocrits lower than 30 excludes anaesthesia as the major cause of the increase.

It was assumed that ISA-diseased fish would show high lactate levels since the anaemia condition probably would put serious limitations on oxygen transport to the tissues. Atlantic salmon, like other salmonids, is an oxygen-demanding species and poorly tolerates low oxygen tensions in the water. In rainbow trout 90 to $95 \%$ of the oxygen consumed by the tissues in the resting fish is transported by haemoglobin (Randall 1970). By carbon monoxide blocking of $94 \%$ of the available haemoglobin, Holeton (1971) found that rainbow trout could not survive more than $30 \mathrm{~min}$ at $10^{\circ} \mathrm{C}$. The sampled individuals in the present experiment were not showing anaemia as severe as in Holeton's (1971) experiment. However, they were likely in a state of hypoxia. The high lactate levels were probably not a product of exercise since ISA fish normally show a sluggish behaviour. Lactate is produced from glucose in anaerobic glycolysis Convertible sources of glucose are glycogen from muscle and liver, and substrates for gluconeogenesis.
Among the metabolic effects of cortisol are an increase in free amino acids in the blood and a stimulation of gluconeogenesis (van der Boon et al. 1991). However, in spite of the high cortisol level in ISA-diseased fish the levels of metabolizable substrates in plasma have been found to be low (Thorud et al. in press). The liver damage observed in ISA fish (Evensen et al. 1991) could have interfered with metabolic processes in the liver and reduced available metabolizable substrates. This could explain some of the variation in lactate levels among ISA-diseased fish. It seems likely that the high lactate levels were related to the anaemia condition, however other possibilities like viral destruction. of respiratory enzymes cannot be excluded. Contrary to the short-lasting high lactate levels found in Atlantic salmon blood after exercise (Wendt \& Saunders 1973), the high lactate levels in ISA-diseased fish are of a long-lasting nature and must put serious demands on the acid-base regulation of fish suffering from ISA.

Acknowledgements. This study was supported by a scholarship from the Norwegian Agricultural Research Council to Y.A.O

\section{LITERATURE CITED}

Abraham, G. E., Manlimos, F. S., Garza, R. (1977). Radioimmunoassay of steroids. In: Abraham, G. E. (ed.) Handbook of radioimmunoassay. Marcel Dekker Inc., New York, p. 591-656

Barton, B. A., Iwama, G. K. (1991). Physiological changes in fish from stress in aquaculture with emphasis on the response and effects of corticosteroids. Ann. Rev. Fish Dis 1: $3-26$

Beisel, W. R. (1977). Magnitude of the host nutritional responses to infection. Am. J. Clin. Nutr. 30: 1236-1247

Berkenbosch, F., Van Oers, J., Del Rey, A., Tilders, F., Besedovsky, H. (1987). Corticotropin-releasing factor-producing neurons in the rat activated by interleukin-1 Science 238: $524-526$

Bernton, E. W., Beach, J. E., Holaday, J. W., Smallridge, R. C., Fein, H. G. (1987). Release of multiple hormones by a direct action of interleukin-1 on pituitary cells. Science 238: $519-521$

Besedovsky, H. O., Sorkin, E., Keller, M., Müller, J. (1975) Changes in blood hormone levels during the immune response. Proc. Soc. exp. Biol. Med, 150: 466-470

Boon, J. van der, Thillart, G. E. E. J. M., Addink, A. D. F. (1991). The effects of cortisol administration on intermediary metabolism in teleost fish. Comp. Biochem. Physiol. 100A: $47-53$

Clem, L. W., Sizemore, R. C., Ellsaesser, C. F., Miller, N. W. (1985). Monocytes as accessory cells in fish immune responses. Dev. comp. Immunol. 9: 803-809

Donaldson, E. M. (1981). The pituitary-interrenal axis as an indicator of stress in fish. In: Pickering, A. D. (ed.) Stress and fish. Academic Press, London, p. 11-47

Donaldson, E. M., Fagerlund, U. H. M. (1968). Changes in the cortisol dynamics of sockeye salmon (Oncorhyncus nerka) resulting from sexual maturation. Gen. comp. Endocrinol. 11: $552-561$ 
Evensen, Ø., Thorud, K. E., Olsen, X. A. (1991). A morphological study of the gross and light microscopic lesions of infectious anaemia in Atlantic satmon (Salmo salar). Res. vet. Sci. 51: 215-222

Fagerlund, U. H. M. (1967). Plasma cortisol concentration in relation to stress in adult sockeye salmon during the freshwater stage of their lite cycle. Gen. comp. Endocrinol. 8: $197-207$

Fagerlund, U. H. M., McBride, J. R. (1969). Suppression by dexamethasone of interrenal activity in adult sockeye salmon (Oncorhyncus nerka). Gen. comp. Endocrinol. 12: $651-657$

Ganong, W. F. (1989). Review of medical physiology, 14th edn. Appleton \& Lange, Los Altos

Holeton, G. F. (1971). Oxygen uptake and transport by the rainbow trout during exposure to carbon monoxide. J. exp Biol. 54: 239-254

Houston, A. H., Madden, J. A., Woods, R. J., Miles, H. M. (1971). Some physiological effects of handling and tricaine methanesulphonate anesthization upon the brook trout. Salvelinus fontinalis. J. Fish. Res. Bd Can. 28: 625-633

Iwama, G. K., Boutilier, R. G., Heming, T A., Randall, D. J., Mazeaud, M. (1987). The effects of aitering giil water flow on gas transfer in rainbow trout. Can. J Zool. 65 $2466-2470$

Iwama, G. K. McGeer, J. C., Pawluk, M. P. (1989). The effects of five fish anaesthetics on acid-base balance, hematocrit. blood gases, cortisol, and adrenaline in rainbow trout. Can. J. Zool. 67: 2065-2073

Laidley, C. W., Woo, P. T K., Leatherland, J. F. (1988). The stress-response of rainbow trout to experimental infection with the blood parasite Cryptobia salmositica Katz, 1951. J. Fish Biol. 32: 253-261

Langhorne, P., Simpson, T. H. (1981). Natural changes in serum cortisol in Atlantic salmon (Salmo salar L.) during parr-smolt transformation. In: Pickering, A.D. (ed.) Stress and fish. Academic Press, London, p. 349-350

Lowe-Jinde, L., Niimi, A. J. (1983). Influence of sampling on the interpretation of haematological measurements of rainbow trout, Salmo gairdneri. Can. J. Zool. 61. 396-402

Melby, J. C., Egdahl, R. H., Spink, W W. (1960). Secretion and metabolism of cortisol after injection of endotoxin. J. Lab. clin. Med. 56: 50-62

Munck, A., Guyre, P. M., Holbrook, N. J. (1984). Physiological functions of glucocorticoids in stress and their relation to pharmacological actions. Endocr. Rev. 5: 25-44

Perry, S. F., Kinkead, R., Gallaugher, P, Randall, D. J. (1989). Evidence that hypoxemia promotes catecholamine release during hypercapnic acidosis in rambow trout (Salmo gairdneri). Resp. Physiol. 77: 351-364

Pickering, A. D. Christie, P. (1981). Changes in the concentrations of plasma cortisol and thyroxine during sexual maturation of the hatchery-reared brown trout. Salmo trutta L. cien. comp. Endocrinol. 44:487-496

Pickering, A. D., Duston, J. (1983). Administration of cortisol to brown trout, Salmo trutta L., and its effects on the susceptibility to Saprolegnia infection and furunculosis. J. Fish Biol. 23: 163-175

Pickering, A. D., Pottinger, T G. (1983). Seasonal and diel changes in plasma cortisol levels of the brown trout. Salmo trutta L. Gen. comp Endocrinol. 49: 232-239

Pickering, A. D., Pottinger, T. G. Christie, P. (1982). Recovery of the brown trout, Salmo trutta L. from acute handling stress: a time-course study. J. Fish Biol. 20: 229-244

Pickering, A. D., Stewart, A. (1984). Acclimation of the interrenal tissue of the brown trout, Salmo trutta L., to chronic crowding stress. J. Fish Biol. 24: 731-740
Rand, T. G., Cone, D. K. (1990). Effects of Ichthyophonus hoferi on condition indices and blood chemistry of experimentally infected rainbow trout (Oncorhyncus mykiss). J. Wildl. Dis. 26: 323-328

Randall, D. J. (1970). Gas exchange in fish. In: Hoar, W. S., Randall, D. J. (eds.) Fish physiology, Vol. IV. Academic Press, New York, p. 253-292

Sapolsky, R., Rivier, C., Yamamoto, G., Plotsky, P., Vale, W. (1987). Interleukin-1 stimulates the secretion of hypothalamic corticotropin-releasing factor. Science 238 $522-524$

Simpson, T. H. (1975/76). Endocrine aspects of salmonid culture. Proc. R. Soc. Edinb. (B) 75: 241-252

Soivio, A., Nikinmaa, M. (1981). The swelling of erythrocytes in relation to the oxygen affinity of the blood of the rainbow trout, Salmo gairdneri Richardson. In: Pickering, A. D. (ed.) Stress and fish. Academic Press, London, p. $103-119$

Soivio, A., Vyholm, K., Huhti, M. (1977). Effects of anaesthesia with MS 222, neutralized MS 222 and benzocaine on the blood constituents of rainbow trout, Salmo gairdneri. J. Fish Biol. 10: 91-101

Steíansson, S. O., Naevdai, G., Hansen, T (1989). The infiuence of three unchanging photoperiods on growth and parr-smolt transformation in Atlantic salmon, Salmo salar L. J. Fish Biol. 35: 237-247

Suzumoto, B. K., Schreck, C. B., McIntyre, J. D. (1977). Relative resistance of three transferrin genotypes of coho salmon (Oncorhyncus kisutch) and their hematological responses to bacterial kidney disease. J. Fish. Res. Bd Can. 34: $1-8$

Tam, W. H., Birkett, L., Makaran, R., Payson, P. D., Whitney, D. K., Yu, C. K.-C. (1987). Modification of carbohydrate metabolism and liver vitellogenic function in brook trout (Salvelinus fontinalis) by exposure to low $\mathrm{pH}$. Can. J. Fish. Aquat. Sci. 44: 630-635

Thorpe, J. E., McConway, M. G., Miles, M. S., Muir, J. S. (1987). Diel and seasonal changes in resting plasma cortisol levels in juvenile Atlantic salmon, Salmo salar L. Gen. comp. Endocrinol. 65: 19-22

Thorud, K. E. (1991). Infectious salmon anaemia: transmission trials indicating a viral cause of the disease in Atlantic salmon (Salmo salar). In: Thorud, K. E. Infectious salmon anaemia. Transmission trials. Haematological, clinical chemical and morphological investigations. Dr. scient. thesis, Norwegian College of Veterinary Medicine, p. $17-29$

Thorud, K. E. (in press). Hematological changes in Atlantic salmon (Salmo salar) suffering from infectious salmon anemia. Dis. aquat. Org.

Thorud, K., Djupvik, H. O. (1988). Infectious anaemia in Atlantic salmon (Salmo salar L.). Bull. Eur. Ass. Fish Path. 8: $109-111$

Thorud, K. E., Olsen, Y. A., Evensen, $\varnothing$. (in press). Changes in plasma parameters in Atlantic salmon (Salmo salar), during development of infectious salmon anemia. Dis. aquat. Org

Wedemeyer, G. (1969). Pituitary activation by bacterial endotoxins in the rainbow trout (Salmo gairdnerI). J. Bacteriol. 100: $542-543$

Wendt, C. A. G., Saunders, R. L. (1973). Changes in carbohydrate metabolism in young Atlantic salmon in response to various forms of stress. Spec. Publ. Int. Atlant. Salm. Found. 4: 55-82

Woloski, B. M. R. N. J., Smith, E. M., Meyer, W. J. III, Fuller, G. M., Blalock, J. E. (1985). Corticotropin-releasing activity of monokines. Science 230: 1035-1037

Manuscript first received: May 19, 1992

Revised version accepted: August 10, 1992 